\title{
New data on the jumping spiders (Araneae: Salticidae) from India
}

\section{Новые данные о пауках-скакунчиках (Araneae: Salticidae) Индии}

\author{
John T.D. Caleb \\ Ажон Т.А. Камеб
}

Department of Zoology, Madras Christian College, Tambaram, Chennai-59, Tamil Nadu, India; e-mail: caleb87woodgate@gmail.com

KEY WORDS: India, new combinations, synonyms, Salticidae, taxonomic remarks.

КЛЮЧЕВЫЕ СЛОВА: Индия, новые комбинации, синонимы, Salticidae, таксономические заметки.

ABSTRACT. Taxonomic notes are given for five species of the jumping spiders from India. Two new combinations are proposed: Chrysilla volupe (Karsch, 1879) comb.n., ex Phintella; and Phintella diatreta (Simon, 1902) comb.n., ex Viciria. Four new synonyms are recognised: Chrysilla assamensis Ahmed, Anam, Saikia, Manthen et Saikia, 2014 with C. acerosa Wang et Zhang, 2012; Plexippus bhutani Żabka, 1990 and $P$. yinae Peng et Li, 2003 with Plexippus clemens O. Pickard-Cambridge, 1872; and Plexippus gajbei Karthikeyani et Kannan, 2013 with Carrhotus viduus C.L. Koch, 1846. P. clemens is recorded from India for the first time.

РЕЗЮМЕ. Представлены таксономические заметки по пяти видам пауков-скакунчиков из Индии. Предложено две новые комбинации: Chrysilla volupe (Karsch, 1879) comb.n., еx Phintella; и Phintella diatreta (Simon, 1902) comb.n., ex Viciria. Предложено четыре новых синонима: Chrysilla assamensis Ahmed, Anam, Saikia, Manthen et Saikia, 2014 c C. acerosa Wang et Zhang, 2012; Plexippus bhutani Żabka, 1990 и P. yinae Peng et Li, 2003 с Plexippus clemens O. Pickard-Cambridge, 1872; и Plexippus gajbei Karthikeyani et Kannan, 2013 c Carrhotus viduus C.L. Koch, 1846. P. clemens впервые указан для фауны Индии.

\section{Introduction}

The salticid fauna of India presently consists of 226 species in 76 genera [Prószyński, 2016b,c; WSC, 2016]. The diversity of Indian Salticidae is expected to be very high because India is considered one of the world biodiversity hotspots [Chitale et al., 2014]. Our knowledge on the Indian Salticidae remains poor and highly fragmented mainly because their diversity is yet underexplored [Prószyński, 1992; Caleb et al., 2015]. While hundreds of species still await discovery, many of those described from India have been misplaced in wrong genera. Moreover, most of the presently known species cannot be positively identified using the existing descriptions without a re-examination of the correspond- ing types [Prószyński, 1992]. This taxonomic impediment needs to be resolved in order to avoid confusion leading to misidentifications and inappropriate placement of taxa in seemingly related groups. The present paper is a follow-up of a recent paper on the salticids of South India by Caleb \& Mathai [2014]. Prószyński [2016a] in his online database, 'Monograph of Salticidae of the world' provisionally suggested some changes in the taxonomic assignment of several Indian salticid species. These changes were updated by Prószyński \& Caleb [2015] in the supplement to the latter database. The aims of the present paper are (1) to formally justify some of the aforementioned transfers and (2) to establish new synonymies of some salticid species from the Indian fauna.

\section{Materials and methods}

The photographs of $P$. clemens were taken by the Leica MC120 HD digital camera attached to the Leica S8APO stereoscopic microscope. The photographs of the holotype of $P$. gajbei were obtained by the Leica DFC500 HD digital camera attached to the Leica M205 A stereomicroscope. All images were then processed with the aid of LAS core software. The nomenclature follows the WSC [2016]. Species were identified by means of the illustrations provided by Prószyñski [2003, 2016a,b] and Logunov [2010]. The studied specimens have been deposited in the National Zoological Collection at the Zoological Survey of India, Southern Regional Centre, Chennai (ZSI-SRC).

\section{Taxonomy \\ Chrysilla volupe (Karsch, 1879), comb.n. Map.}

Attus volupe Karsch, 1879: 552.

Phintella volupe: Żabka, 1988: 465, figs 122-125.

Phintella volupe: Caleb, Mathai, 2014: 64, figs 15-23.

REMARKS. The palpal structure of C. volupe strongly resembles that of $C$. lauta Thorell, 1887, the type species of the genus Chrysilla Thorell, 1887. Żabka 


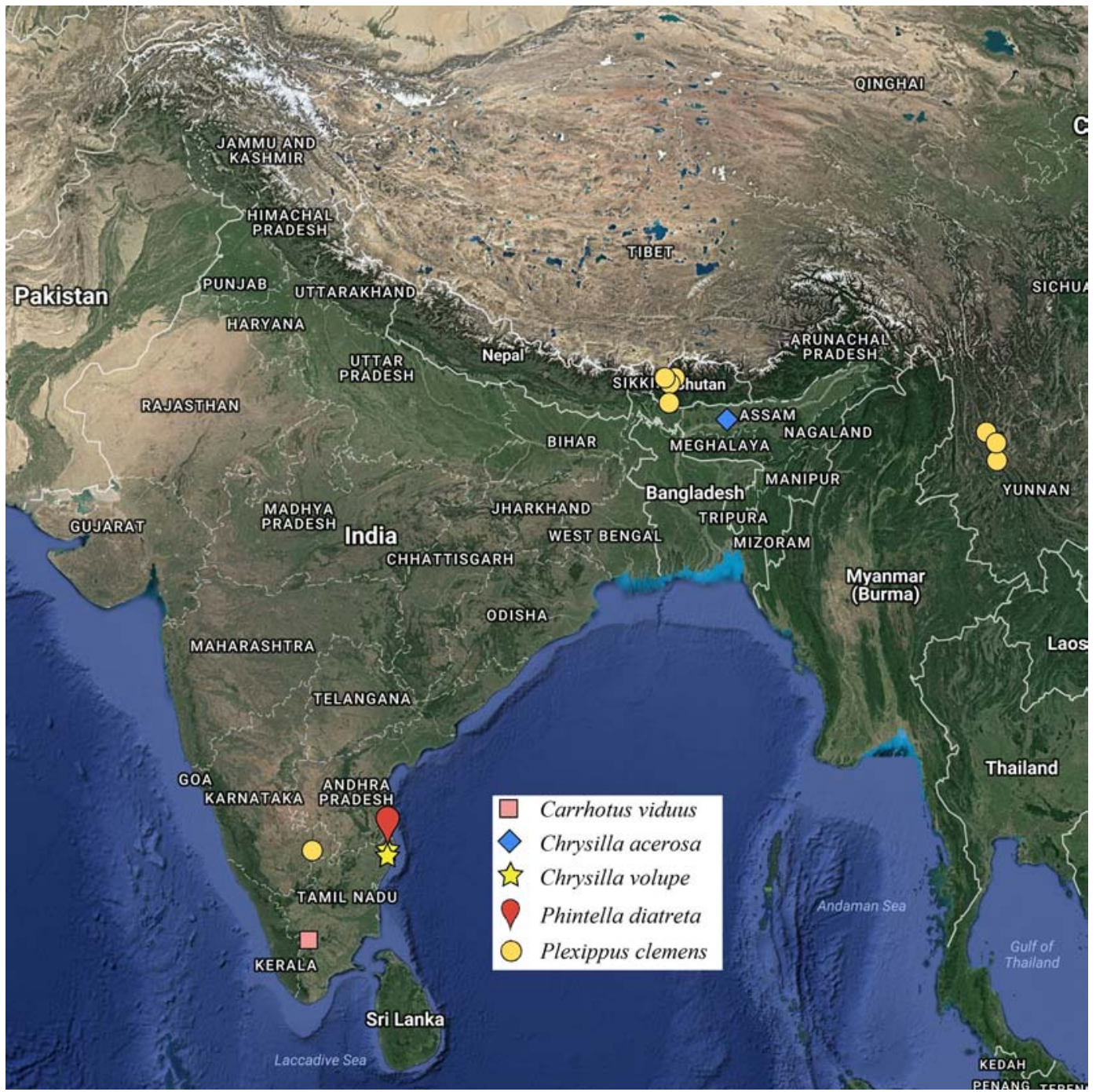

Map. Distributional records of the studied jumping spiders in India, Bhutan and China.

Карта. Точки распространения изученных видов пауков-скакунчиков в Индии, Бутане и Китае.

[1988] mistakenly placed this species in Phintella Strand, 1906. Chrysilla can be distinguished from Phintella by the following characters: the presence of colorful body iridescent scales; abdomen of Chrysilla species is longer and narrow than that of Phintella; the male palp possesses the thin, slender embolus (short and thick in Phintella); and the retrolateral tibial apophysis is single and strong. The drawings by Żabka [1988] and photographs by Caleb \& Mathai [2014], when compared to the palpal structure of C. lauta illustrated by Prószyński [1983], strongly suggest that Phintella volupe needs to be moved to Chrysilla. Its relationship with the type species $(C$. lauta) remains poorly resolved. Both species are similar in their general appearance except for the presence of a M-shaped orange abdominal band in $C$. volupe and slight variations in the conformation of the tibial apophyses, which seem to differ between the two species. An examination of more material taken from the type locality of C. lauta is necessary, as it is likely that both species could be conspecific, thus revealing a much wider distribution of $C$. volupe.

DISTRIBUTION. India, Sri Lanka, Bhutan (Map) [WSC, 2016].

\section{Chrysilla acerosa Wang et Zhang, 2012 Map.}

Chrysilla acerosa Wang et Zhang, 2012: 65, figs 1-18 (the $\sigma^{7}$ holotype from the School of Life Science, Southwest University, Chongqing, China; not examined).

Chrysilla assamensis Ahmed, Anam, Saikia, Manthen et Saikia, 2014: 39, figs 1-18, syn.n. (the $\sigma^{7}$ holotype from the Biodiversity Museum, Gauhati University, India; not examined).

REMARKS. C. assamensis was described on the basis of a single male collected from Sontipur, Assam, India. Ahmed et al. [2014] provided very detailed and reliable photographs of the male palp that show all the diagnostic characters of C. acerosa: viz., the long and slender embolus, the wide retrolateral tibial apophysis, 

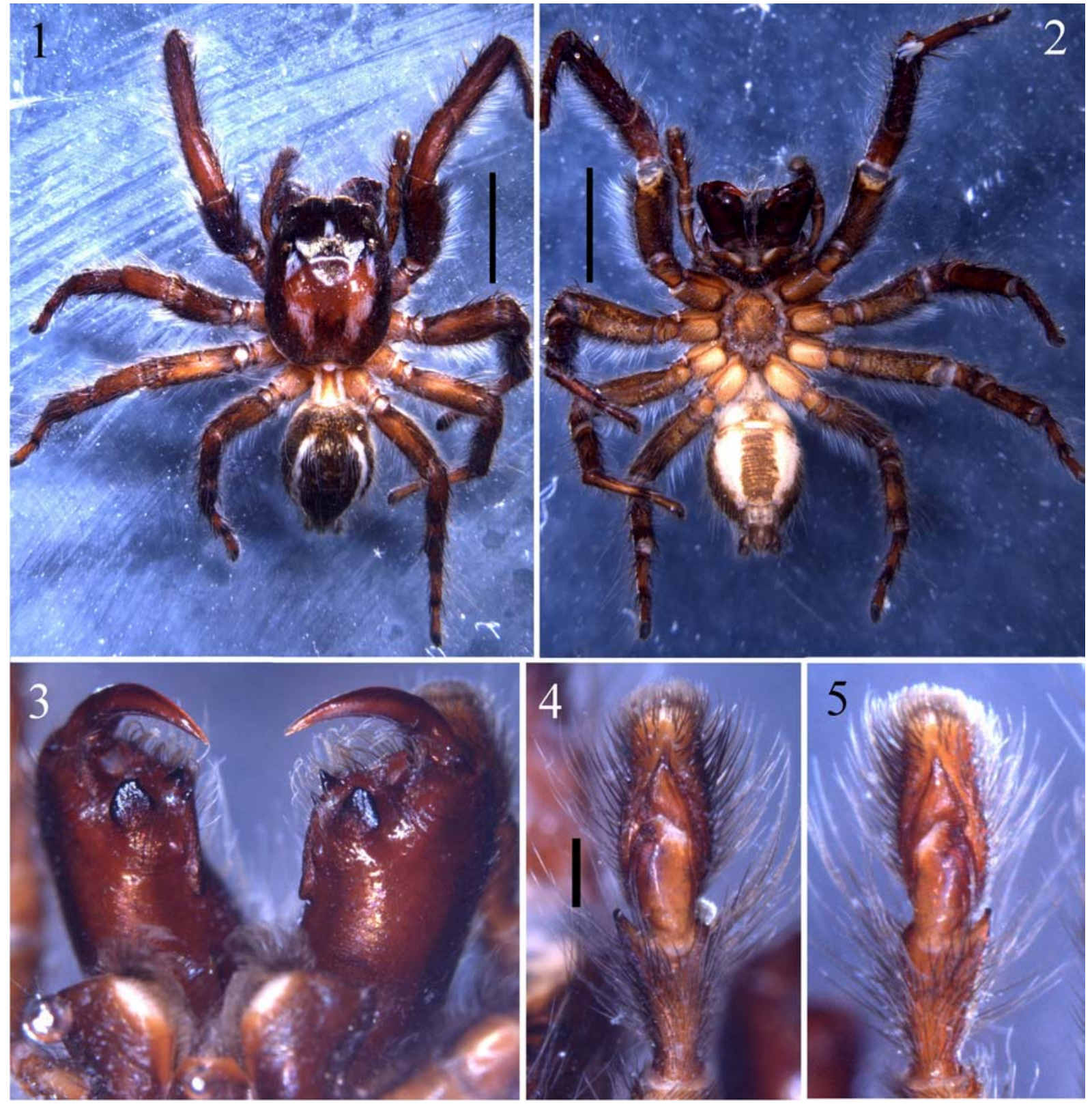

Figs 1-5. General appearance and copulatory organs of C. viduus C.L. Koch, 1846 ( $\odot^{7}$ holotype of $P$. gajbei Karthikeyani et Kannan, 2013). 1 - male, dorsal view; 2 - ditto, ventral view; 3 - male chelicerae, ventral view; 4 - male right palp, ventral view; 5 - male left palp, ditto. Scale bars: (1-2) $2 \mathrm{~mm}$; (4) $0.5 \mathrm{~mm}$.

Рис. 1-5. Общий вид и копулятивные органы C. viduus C.L. Koch, 1846 (голотип Оフ P. gajbei Karthikeyani et Kannan, 2013). 1 - самец, вид сверху; 2 - тоже, вид снизу; 3 - хелицеры самца, вид снизу; 4 - правая пальпа самца, вид снизу; 5 - левая пальпа самца, тоже. Масштаб: (1-2) 2 мм; (4) 0,5 мм.

with its tip projecting ventrad (cf. figs 4-5, 13 \& 14 in Wang \& Zhang [2012] and figs 9-10, 12 \& 13 in Ahmed et al. [2014]). Since the conformation of the male palp in both species is identical, it is safe to conclude that the species name $C$. assamensis is to be synonymized with C. acerosa.

DISTRIBUTION. China, India (new record) (Map) [Wang, Zhang, 2012; Ahmed et al., 2014: sub. C. assamensis].
Carrhotus viduus C.L. Koch, 1846

Figs 1-5, Map.

Plexippus viduus C.L. Koch, 1846: 104, fig. 1166.

Carrhotus viduus: Jastrzębski, 1999: 4, figs 8-11.

Plexippus gajbei Karthikeyani et Kannan, 2013: 43, figs 1a-c, images 1-2, syn.n. (the $\sigma^{7}$ holotype from the Zoological Survey of India; examined, Figs 1-5).

For a complete list of taxonomic references see WSC [2016]. 
TYPE. Holotype $\sigma^{7}$ of P. gajbei (ZSI-SRC-I/SP 6) from India, Tamil Nadu, Western Ghats, Kumbakarai Falls. The original paper [Karthikeyani, Kannan, 2013: 44 , figs $1 \mathrm{~b}, \mathrm{c}]$ mentioned the $\rightarrow$ holotype, whereas the real material preserved in the collection at the Zoological Survey of India (Chennai) is $\sigma^{7}$; it is actually belongs to Carrhotus viduus (C.L. Koch, 1846).

REMARKS. Plexippus gajbei was described on the basis of a single male collected from Kumbakarai falls, Madurai, India. However, the original paper [Karthikeyani, Kannan, 2013: 44, fig. 1] presented confusing information. Although the text [Ibid., 2013: 43-44] mentioned the female holotype, it also presented two photos of the male [Ibid., 2013: images 1-2]. Having examined the specimen labelled as the holotype of $P$. gajbei, which is deposited in the Zoological Survey of India (see above), it has been found out that it is the male that actually belong to $C$. viduus (see Figs 4-5); reported by Karthikeyani \& Kannan [2013: images 12]. The ventral view shows the same male after it was preserved.

The matter is rather confusing, raising some doubts on whether the species was really described from the female, as claimed by the authors [Karthikeyani, Kannan, 2013: 44], or perhaps the holotype was mixed up with other specimens in the collection. The latter assumption is highly unlikely, because the authors deposited only two specimens in the collection of the Zoological Survey of India, of which one is labelled as the holotype of $P$. gajbei and the other is Peucetia sp. Images 1 and 2 by Karthikeyani, Kannan [2013] undoubtedly show the habitus of a live male specimen with the robust first pair of legs. These images and the habitus drawing conform to those of the deposited and examined male (Fig. 1), and therefore it is safe to conclude that the authors [Karthikeyani, Kannan, 2013] simply mixed up the information and images in their paper.

As the dorsal pattern and the palpal structure clearly match with the illustrations provided by Jastrzębski [1999: fig. 8], the name $P$. gajbei is to be regarded as a junior synonym of $C$. viduus.

DISTRIBUTION. India to China (Map).

Phintella diatreta (Simon, 1902), comb.n.
Map.

Viciria diatreta Simon, 1902: 366.

Viciria diatreta: Prószyński, 1984: 433, figs 42-43.

Viciria diatreta: Caleb, Mathai, 2014: 65, figs 38-46.

REMARKS. The species is known from the male only. In his remarks devoted to Viciria diatreta, Prószyński [1984: 433] mentioned that the species was misplaced in the genus Viciria, but he did not transfer it to another genus. A recent discovery of the male from Chennai enabled the author to study a fresh specimen [Caleb, Mathai, 2014]. The Phintella males are characterized by the following diagnostic characters [see Żabka, 2012]: the embolus is short, pointed and apically set; the tegulum with a proximal lobe and bump; one or more tibial apophyses. Based on the palpal conformation presented both by Prószyński [1984] and by Caleb, Mathai [2014], it is safe to conclude that the species is actually a member of the genus Phintella.

DISTRIBUTION. India (Map).

\section{Plexippus clemens O. Pickard-Cambridge, 1872} Figs 6-17, Map.

Salticus clemens O. Pickard-Cambridge, 1872: 335.

Plexippus clemens: Wesołowska, van Harten, 2007: 246, figs 165-168.

Plexippus tectonicus Prószyński, 2003: 145, figs 581-582, 586, 591, 736-737.

Plexippus bhutani Żabka, 1990: 173, figs 28-33, syn.n. (the $\sigma^{7}$ holotype from the Naturhistorisches Museum, Basel, Switzerland; examined, Figs 12-13).

Plexippus yinae Peng et Li, 2003: 755, figs 5A-E, syn.n. (the $\sigma^{7}$ holotype from the Institute of Zoology, Chinese Academy of Sciences in Beijing, China; not examined).

For a complete list of taxonomic references see WSC [2016].

MATERIAL. INDIA: $1 \sigma^{7}$ (ZSI-SRC I/SP 23), Bangalore, Narayanapura $\left(13^{\circ} 3^{\prime} 34.3794^{\prime \prime} \mathrm{N}, 77^{\circ} 38^{\prime} 47.529^{\prime \prime} \mathrm{E}\right), 896.92 \mathrm{~m}$ a.s.l., 20 March 2015, coll. J. Caleb.

REMARKS. There are two Plexippus species with the similar palpal structures: viz., P. yinae Peng et Li, 2003 and P. bhutani Żabka, 1990. P. bhutani was first described from Bhutan [Żabka, 1990] and later was also reported from China [Xie, Peng, 1993]. Peng, Li [2003] described/reported on five Plexippus species from China, including $P$. bhutani and $P$. yinae from Yunnan province. However, they reported on P. bhutani on the basis of the females and described $P$. yinae from two males. The male palpal structure both of $P$. bhutani and of $P$. yinae shows the short and thick embolus, with the "conductor" visible at its ventrolateral rim (Figs 12 and fig. 5b,c in Peng, Li [2003]) and are identical to those of $P$. clemens (cf. Fig. 8). The epigyne and spermathecae of P. bhutani (Figs 16, 17) do not differ from those of $P$. clemens as well [cf. Wesołowska, van Harten, 2007]. Minor variations in the structure of the copulatory organs can be considered an intraspecific variation seen across different geographical regions. Thus, it is safe to conclude that both $P$. yinae and $P$. bhutani are to be regarded as junior synonyms of $P$. clemens.

DISTRIBUTION. $P$. clemens is a widespread species known from Turkey, Libya, Egypt, Israel, Yemen, Iran, India (new record, Map), Bhutan and China (Yunnan) [WSC, 2016; present data].

ACKNOWLEDGEMENTS. I am grateful to Dr K. Ilango, Officer-in-charge at the Zoological Survey of India, Southern Regional Centre (ZSI-SRC), Chennai, for allowing me to examine and photograph the holotype of Plexippus gajbei deposited in their collection. Sincere thanks go to Dr Krushnamegh Kunte, Lab 8, National Centre for Biological Sciences (NCBS), Bangalore for allowing me to use their stereomicroscope. I am very obliged to Dr Ambros Hänggi, Curator at Naturhistorisches Museum, Basel, Switzerland, for kindly providing me with digital photographs of 

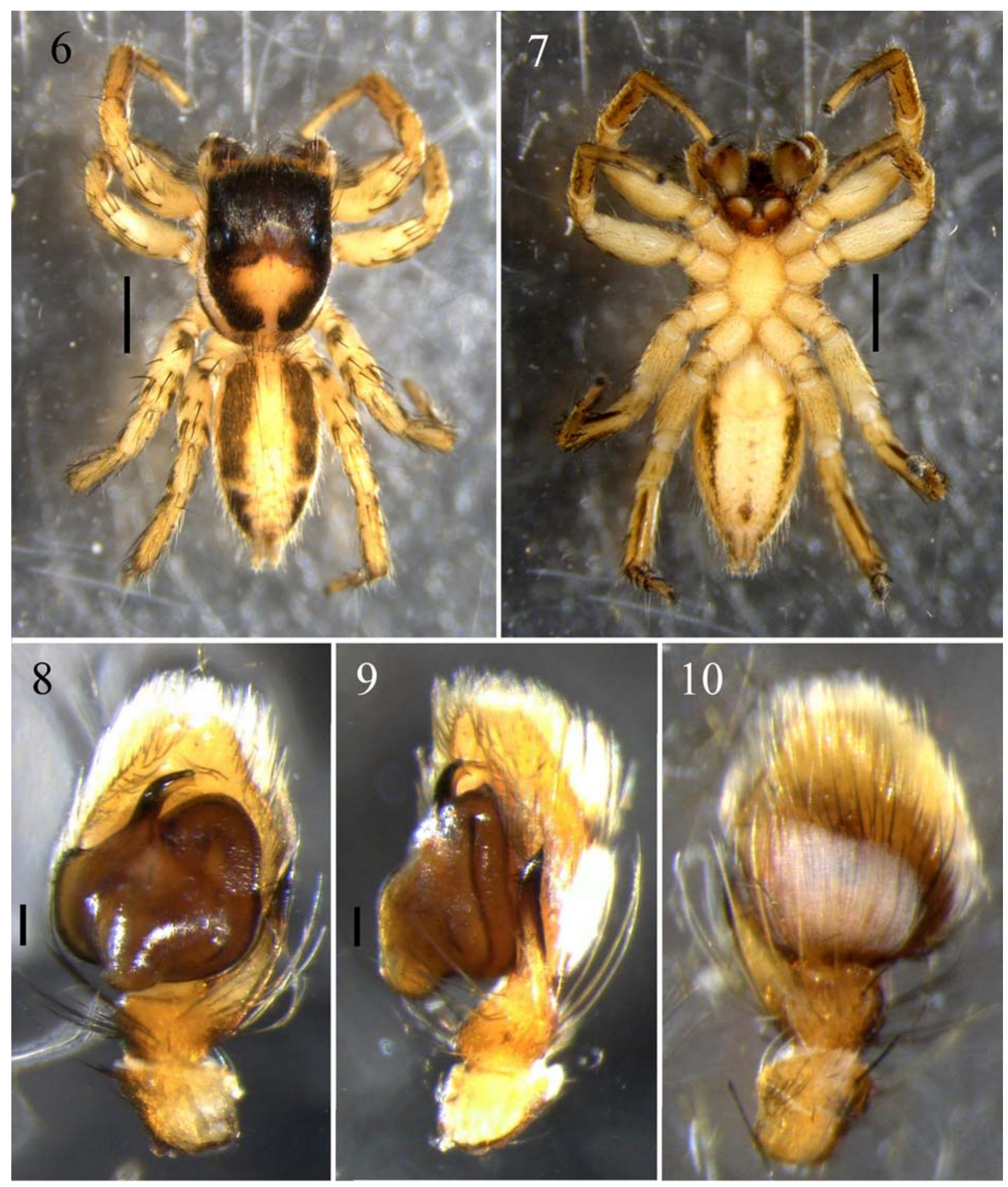

Figs 6-10. General appearance and copulatory organs of Plexippus clemens O. Pickard-Cambridge, 1872 from India. 6 - male, dorsal view; 7 - ditto, ventral view; 8 - male palp, ventral view; 9 - ditto, retrolateral view; 10 - ditto, dorsal view. Scale bars: (6-7) $1 \mathrm{~mm}$; (8-9) $0.1 \mathrm{~mm}$.

Рис. 6-10. Общий вид и копулятивные органы Plexippus clemens O. Pickard-Cambridge, 1872 из Индии. 6 - самец, вид сверху; 7 - тоже, вид снизу; 8 - пальпа самца, вид снизу; 9 - тоже, ретролатерально; 10 - тоже, вид сверху. Масштаб: (6-7) 1 мм; (89) $0,1 \mathrm{mм}$. 

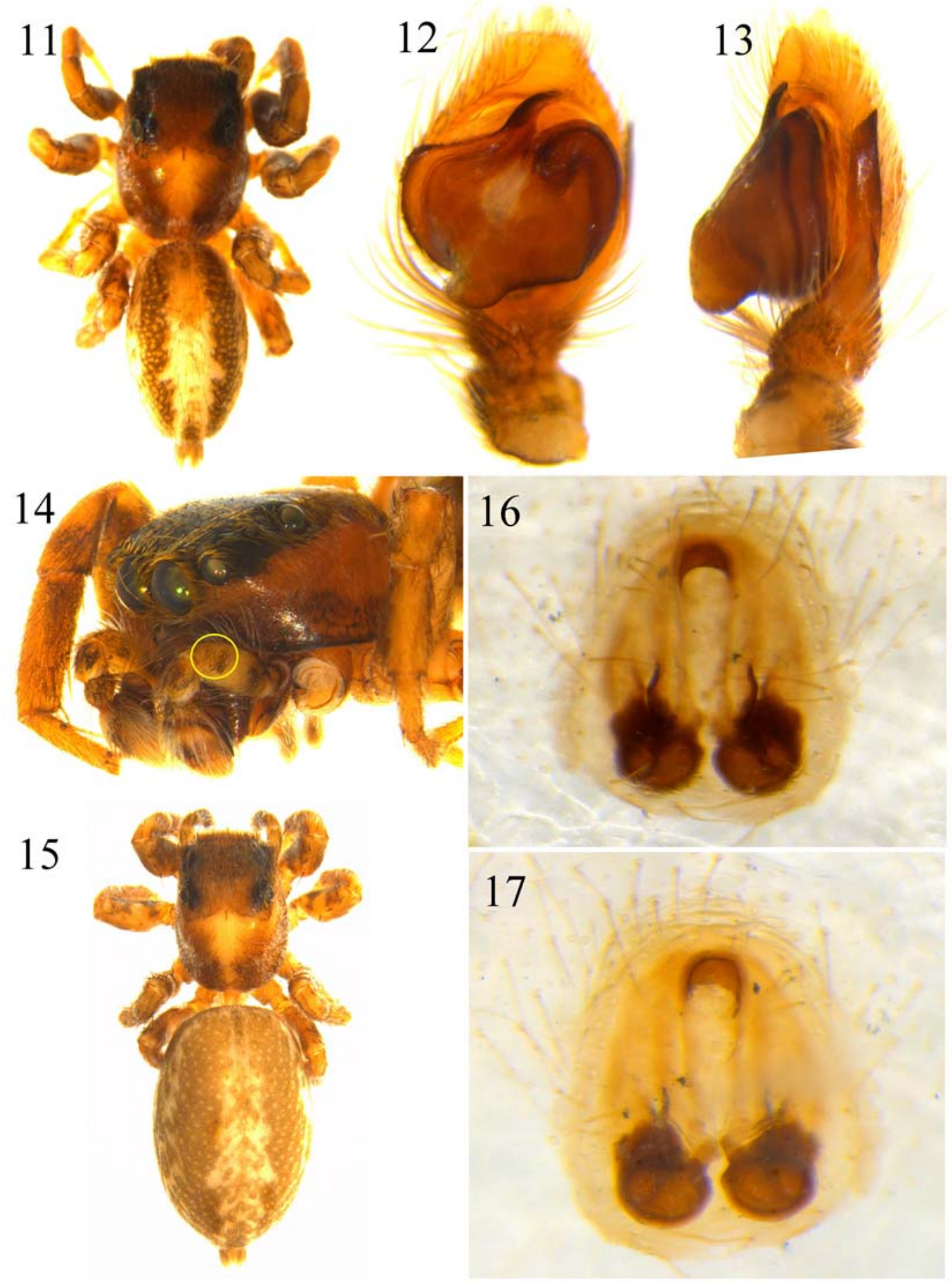

Figs 11-17. General appearance and copulatory organs of Plexippus clemens O. Pickard-Cambridge, $1872\left(O^{7}\right.$ holotype and $q$ paratype of Plexippus bhutani Żabka 1990). 11 - Male holotype, dorsal view; 12 - male palp, ventral view; 13 - ditto, retrolateral view; 14 - male paratype, carapace, lateral view showing palpal femur with long black hairs; 15 - female paratype, dorsal view; 16 - epigyne, ventral view; 17 - spermathecae, dorsal view. Images kindly provided by Dr Ambros Hänggi from Naturhistorisches Museum, Basel, Switzerland.

Рис. 11-17. Общий вид и копулятивные органы Plexippus clemens O. Pickard-Cambridge, 1872 (голотип О7 и паратип + Plexippus bhutani Żabka 1990). 11 — голотип, самец, вид сверху; 12 — пальпа самца, вид внизу; 13 — тоже, ретролатерально; 14 паратип, головогрудь самца, вид сбоку показывающий бедро пальпы с длинными черными волосками; 15 - паратип, самка, вид сверху; 16 - эпигина, вид снизу; 17 - сперматека, вид сверху. Изображения любезно предоставлены Dr Ambros Hänggi from Naturhistorisches Museum, Basel, Switzerland. 
the types of Plexippus bhutani Żabka, 1990 (Figs 11-17). Dr David Hill is cordially thanked for his suggestions on the earlier draft of the ms. Finally, Dr Dmitri Logunov (Manchester, UK) is thanked for his editorial and linguistic help.

\section{References}

Ahmed M., Anam J., Saikia M.K., Manthen S.V., Saikia, P.K. 2014. Records of new genus Chrysilla (group spider: suborder: Araneae: family: Salticidae) in India at agroecosystem, at Sonitpur, Assam // Journal on New Biological Reports. Vol.3. No.1. P.38-43.

Caleb T.D.J., Mathai M.T. 2014. Description of some interesting jumping spiders (Araneae: Salticidae) from South India // Journal of Entomology and Zoology Studies. Vol.2. No.5. P.63-71.

Caleb T.D.J., Mungkung S., Mathai M.T. 2015. Four new species of jumping spider (Araneae: Salticidae: Aelurillinae) with the description of a new genus from South India // Peckhamia. Vol.124. No.1. P.1-18.

Chitale V.S., Behera M.D., Roy P.S. 2014. Future of endemic flora of biodiversity hotspots in India // PLoS ONE. Vol.9. No.12: e115264. doi:10.1371/journal.pone.0115264

Jastrzębski P. 1999. Salticidae from the Himalaya: the genus Carrhotus Thorell 1891 (Araneae, Salticidae) // Senckenbergiana Biologica. Bd.79. H.1. P.1-9.

Karsch F. 1879. Arachnologische Beiträge // Zeitschrift für die Gesammten Naturwissenschaften. Bd.52. S.534-562.

Karthikeyani R., Kannan S. 2013. A new Plexippus spider from the western Ghats, Kumbakarai Falls, Theni District, Tamil Nadu, south India (Arachnida: Araneae: Salticidae) // Indian Journa of Arachnology. Vol.2. No.2. P.42-46.

Koch C.L. 1846. Die Arachniden. Nürnberg. Dreizehnter Band, S. 1-234; Vierzehnter Band, S. 1-88.

Logunov D.V. 2010. Taxonomic notes on a collection of jumping spiders from Iran (Araneae, Salticidae) // Bulletin of the British Arachnological Society. Vol.15. Pt.3. P.85-90.

Peng X.J., Li S.Q. 2003. Spiders of the genus Plexippus from China (Araneae: Salticidae) // Revue Suisse de Zoologie. T.110. Fasc.4. P.749-759.

Pickard-Cambridge O. 1872. General list of the spiders of Palestine and Syria, with descriptions of numerous new species, and characters of two new genera // Proceedings of the Zoological Society of London. Vol.1871. P.212-354.

Prószyński J. 1983. Position of genus Phintella (Araneae: Salticidae) // Acta Arachnologica. Vol.31. No.2. P.43-48.

Prószyński J. 1984. Remarks on Viciria and Telamonia (Araneae, Salticidae) // Annales zoologici, PAN. T.37. No.18. P.417436.
Prószyński J. 1992. Salticidae (Araneae) of India in the collection of the Hungarian National Natural History Museum in Budapest // Annales Zoologici, PAN. T.44. No.9. P.165-277.

Prószyński J. 2016a. Monograph of Salticidae (Araneae) of the World 1995-2015. Part I: Introduction to alternative classification of Salticidae; online at: http://www.peckhamia.com/salticidae/Subfamilies/ (Accessed on 23rd May 2016).

Prószyński J. 2016b. Monograph of Salticidae (Araneae) of the World 1995-2015. Part II: Global Species Database of Salticidae (Araneae); online at: http://www.peckhamia.com/salticidae/ (Accessed on 23rd May 2016).

Prószyński J. 2016c. Delimitation and description of 19 new genera, a subgenus and a species of Salticidae (Araneae) of the world // Ecologica Montenegrina. Vol.7. P.4-32.

Prószyński J., Caleb J.T.D. 2015. Key to identification of Salticidae (Araneae) of the Indian Subcontinent. http://www. peckhamia.com/salticidae/index_India.html (Accessed on 30th November 2015).

Simon E. 1902. Description d'arachnides nouveaux de la famille des Salticidae (Attidae) (suite) // Annales de la Société Entomologique de Belgique. T.46. P.24-56, 363-406.

Thorell T. 1887. Viaggio di L. Fea in Birmania e regioni vicine. II. Primo saggio sui ragni birmani // Annali del Museo Civico di Storia Naturale di Genova. T.25. P.5-417.

Wang L.Y., Zhang Z.S. 2012. A new species of Chrysilla Thorell, 1887 from China (Araneae: Salticidae) // Zootaxa. Vol.3243. P.65-68.

WSC 2016. World Spider Catalog. Natural History Museum Bern; online at: http://wsc.nmbe.ch, version 17 (accessed on 23rd March 2016).

Żabka M. 1985. Systematic and zoogeographic study on the family Salticidae (Araneae) from Viet-Nam // Annales Zoologici, PAN. T.39. No.11. P.197-485.

Żabka M. 1988. Salticidae (Araneae) of Oriental, Australian and Pacific regions III // Annales Zoologici, PAN. T.41. No.14. P.465-466.

Żabka M. 1990. Salticidae from the Nepal and Bhutan Himalayas. Genera Pancorius Simon 1902, Plexippus C.L. Koch 1846, and Pseudamycus Simon 1885 (Arachnida: Araneae) // Senckenbergiana Biologica. Bd.70. H.1/3. P.161-178.

Żabka M. 2012. Phlegra Simon, 1876, Phintella Strand 1906 and Yamangalea Maddison, 2009 (Arachnida: Araneae: Salticidae) - new species and new generic records for Australia // Zootaxa. Vol. 3176. P.61-68.

Xie L.P., Peng X.J. 1993. One new species and two newly recorded species of the family Salticidae from China (Arachnida: Araneae) // Acta Arachnologica Sinica. Vol.2. No.1. P.19-22.

Wesołowska W., van Harten A. 2007. Additions to the knowledge of jumping spiders (Araneae: Salticidae) of Yemen // Fauna of Arabia. Vol.23. P.189-269.

Responsible editor D.V. Logunov 